\title{
ANTEPROJETO DO ESTATUTO DOS FUNCIONÁRIOS PÚBLICOS CIVIS DA UNIÃO
}

\author{
Dispōe sobre o regime \\ jurídico dos Funcionários Públicos Civis da \\ Uniāo, dos Territórios e das Autarquías \\ federais, e dá outras providéncias.
}

\section{TÍTULO I \\ Disposições Preliminares}

\section{CAPÍTULO ÚNICO}

Art. 1. - Esta Lei dispõe sobre o regime juridico dos Funcionários Públicos Civis da Uniāo, dos Territórios e das Autarquias federais.

Art. 2:- Na aplicação desta Lei, serão observadas as seguintes definiçōes:

I - cargo público é conjunto de atribuiçôes a serem desempenhadas por uma pessoa dentro de uma estrutura organizacional, criado por lei, com denominação própria e pago pelos cofres públicos;

II - funcionário público é a pessoa legalmente investida em cargo público.

Parágrafo único - É vedado cometer ao funcionário atribujções diferentes das de seu cargo.

Art. 3. - É proibida a prestaçāo de serviços gratuitos, salvo no caso de desempenho de funçāo transitória de natureza especial, ou no de participaçào em comissões ou grupos de rrabalho para elaboração de projetos de interesse nacional.

\section{TÍTULO II \\ Do Provimento, \\ Vacância e \\ Movimentação}

\section{CAPÍTULO I}

\section{Do Provimento}

\section{SEÇÃO I \\ Disposições Gerais}

Art. 4: - Sāo requisitos básicos para ingresso no serviço público:

l - ter nacionalidade brasileira ou equiparada;

11 - estar no gozo dos direitos políticos;

Ill - estar em dia com as obrigações militares e eleitorais;

IV - ter nivel de escolaridade ou habilitaçāo legal para o exercicio do cargo.

Parágrafo único. As atribuiçôes do cargo podem justificar a exigência de outros requisitos, na forma estabclecida em lei ou regulamento.

Art. 5. - Ressalvados os casos previstos em lei, é exigida a idade minima de dezoito e a máxima de sessenta anos completos, na data do encerramento da inscriçāo em concurso público.
Parágrafo único. - Nāo dependerá de limite de idade a inscriçāo em concurso do ocupante de cargo público federal de provimento efetivo.

Art. $6^{\circ}-\AA$ A pessoa deficiente é assegurado o direito de candidatar-se ao ingresso no serviço público para o exercicio de cargos cujas atribuiçôes não sejam incompativeis com a deficiência de que é portadora.

Parágrafo único. - Ao funcionário admitido nāo se concederão quaisquer vantagens, direilos ou beneficios em razāo da deficiĉncia existente à ćpoca da admissāo.

Art. $7^{\circ}$ - São formas de provjmento de cargo público:

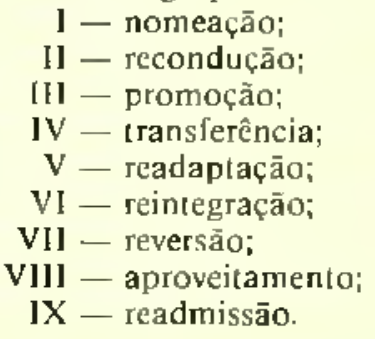

\section{SECÃO II Da Nomeaçāo}

Art. $8^{\circ}-\mathrm{A}$ nomeaçāo far-sc-á: I - em caráter efetiva, quando se tratar de cargo de carreira;

11 - em comissảo, quando se tratar de cargo que em virtude de lei, seja de livre nomeaçāo e exoneraçāo, saisf́eitos os requisitos legais e regulamentares.

Art. 9! - A nomeaçāo para cargo de provimento efetivo depende de prévia habilitação em concurso público de provas ou de provas e títulos, obedecida a ordem de classificaçâo. 
Art. 10 - Dentre os candidatos aprovados, os classificados até o limite de vagas, existentes à época do edital, rêm assegurado o direiro à nomeaçāo, no prazo de validade do concurso.

Parágrafo único - Os demais candidatos aprovados serão nomeados à medida que ocorrerem vagas, dentro do prazo de validade do concurso.

Art. 11 - O regulamento ou ediral do concurso indicará o respectivo prazo de validade, que nāo poderá ser superior a quatro anos, incluidas as prorrogaçōes.

\section{SEÇÃO III Da Posse e do Exercício}

Art. 12 - Posse é a aceitação formal das atribuiçōes, deveres e responsabilidades inerentes ao cargo públi$\mathrm{Co}_{1}$ com o compromisso de bem servir.

\$ 1. A posse ocorrerá no prazo de sessenta dias contados da publicaçāo do ato de provimento.

$\S 2{ }^{\circ}$ Em se tratanto de funcionário em licença ou outro afastamento legal, o prazo é contado do término do impedimento.

ริ 3? Nāo há posse nos casos de provimento por promoçāo, reintegraçāo, recondução e transferência.

$\S 4$. A posse é formalizada com a assinatura do termo pela autoridade competente e pelo empossando.

Art. 13 - A posse em cargo pú blico depende de prévia inspeçāo médica, para comprovar se o candidato satisfaz os requisitos físicos e mentais exigidos para o desempenho do cargo.

Art. 14-O exercicio terá início no prazo de trinta dias contados da posse.

Parágrafo único - Tornar-se-á sem eleito o alo de provimento se o funcionário nāo entrar em exercício no prazo legal.

Art. 15 - O funcionário que deva ter exercicio em outra sede terá trinta dias, contados do desligamento do órgão de origem, para assumir o cargo, compreendido o tempo necessário ao deslocamento para a nova sede.

Art. $16-\mathrm{O}$ afastamento do funcionário para ter exercício em outro órgāo ou entidade, ou para estudo ou missão oficial no exterior, será disciplinado em regulamento.

\section{SECCÃO IV Do Estágio Probatório}

Art. 17 - Ao entrar em exercício, o funcionário nomeado para cargo de provimento efetivo ficará sujeito a estágio probatório por período de até dois anos, durante o qual sua aptidão e capacidade serão objeto de avalia çāo para o desempenho do cargo.

Parágrafo único - Dentro do período do estágio probatório, a autoridade competente fica obrigada a pronunciar-se sobre o cumprimento das condiçōes pelo estagiário, nos termos do regulamento.

Art. 18 - O funcionário nāo aprovado no estágio será exonerado ou, se estável, reconduzido ao cargo anteriormente ocupado.

\section{SEÇĀO V Da Estabilidade}

Art. 19 - Cumprindo satisfatoriamente o estágio probatório, o funcionário adquirirá a estabilidade no serviço público, após o segundo ano de efetivo exercício.

Art. $21-\mathrm{O}$ funcionário estável somente poderá ser demitido por efeito de sentença judicial ou processo administ rativo.

\section{SEÇ̃̃O VI \\ Da Recondução}

Art. 21 - Recondução é o retorno ao cargo anteriormente ocupado, de funcionário estável inabilitado $\mathrm{cm}$ estágio probatório relativo a outro cargo de provimento efelivo.

Parágrafo único - Se extinto ou transformado o cargo, dar-se-á recondução no resultante da transformação ou em outro de mesmo vencimento e atribuições equivalentes, observada a habilitaçāo legal.

\section{SEÇĀO VII Da Promoção}

Art. 22 - Promoção é a elevaçāo do funcionário a cargo imediatamente superior na estrutura da respectiva carreira.
Art. 23 - A promoção obedecerá a critério de merecimento pelos quais serão aferidas, dentre outros requisitos previstos em regulamento, a capacidade e a habilidade do funcionário para o desempenho do novo cargo.

Art. 24 - Será declarado promo vido o funcionário que:

I - ao se aposentar ou falecer já tenha preenchido os requisitos para a promoção;

II - tenha falecido em conseqüência de acidente em serviço.

\section{SECÃO VIII \\ Da Transferência}

Art. 25 - Transferência é a passagem do funcionário estável para outro cargo de igual denominação e vencimento, que seja integrante de quadro diverso.

Parágrafo único - A transíerência poderá ocorrer a pedido do funcionário, atendida a conveniência do serviço, ou ex officio.

\section{SEÇÃO IX Da Readaptação}

Art. 26 - Readaptaçāo é a investidura em cargo de atribuiçōes e responsabilidades compativeis com a limitação que tenha o funcionário sofrido em sua capacidade física ou mental, apurada por junta médica oficial.

Parágrafo único - A reduçāo ou aumento de vencimento que acaso decorrer da readaptaçāo será disciplinado em regulamento.

\section{SEÇÃo $X$ Da Reintegraçāo}

Art. 27 - Reintegraçāo é o reingresso no serviço público, com ressarcimento das vantagens ligadas ao cargo, por efeito de decisāo administrativa ou judiciária.

§ 10. A reintegração dar-se-á no cargo anteriormente ocupado, no que resultou de sua transformaçāo ou, se extinto, em cargo equivalente, para cujo provimento sejam normalmente exigidas as mesmas qualificaçōes $e$ 
intitulações, e tenha vencimento idêntico.

$\S 2$. Se inviáveis as soluçōes indicadas no parágrafo precedente, será restabelecido automaticamente o cargo anterior, no qual se dará a reintegração.

\section{SEÇĀO XI \\ Da Reversão}

Art. 28 - Reversão é o retorno à atividade do funcionário aposentado por invalidez, quando insubsistentes os motivos determinantes da aposentadoria, declarados por junta médjca oficial.

Art. 29 - A reversão far-se-á no mesmo cargo ou no resultante de sua transformação.

\section{SECÄO XII \\ Do Aproveitamento}

Arr. 30 - Aproveitamento é o retorno à atividade do funcionário em disponibilidade

Art. 31 - $\mathrm{O}$ aproveitamento dependerá de existência de vaga e da capacidade física e mental do funcionário, comprovada por junta médica oficial.

Parágrafo único - Verificada a incapacidade definitiva, o funcionário será aposentado.

Art. 32 - Será tornado sem efeito o aproveitamento e cassada a disponibilidade se o funcionário nāo tomar posse e entrar em exercício no prazo legal, salvo doença comprovada por junta médica oficial.

\section{SECÃO XIII Da Readmissāo}

Art. 33 - Readmissão é o reingresso de ex-funcionário exonerado, a pedido, de cargo de provimento efetivo, atendido o interesse do serviço.

Parágrafo único - Far-se-á a readmissāo no cargo anteriormente ocupado ou em outro de atrihuições análogas e de vencimentos equivalentes, observados os requisitos exigidos para o seu provimento. rá:

Art. 34 - A readmissão depende-
I - da existência de vaga, excluída a destinada à promoção;

II - de capacidade física e mental, comprovada por junta médica oficial.

\section{CAPÍTULO II}

\section{Da Remoção}

Art. 35 - Remoção é a movimentação do funcionário, a pedido ou ex officio, no quadro a que pertence, com ou sem mudança de sede, mediante preenchimento de claro de lotaçāo.

Art. 36 - É assegurada a remoçāo a pedido para outra localidade, por motivo de doença do funcionário, cônjuge ou dependente, comprovada por junta médica oficial.

\section{CAPÍTULO III}

\section{Da Redistribuição}

Art. 37 - Redistribuição é o deslocamento do funcionário para quadro de pessoal de outro órgāo da Uniāo ou de autarquia federal, mediante extinção de seu cargo no quadro de origem e criação automática do cargo no quadro de destino.

Art. 38 - A redistribuição ocorrerá em uma das seguintes hipóteses: I - reorganização ou extinção de órgāo ou autarquia federal;

II - criação de novo órgão ou autarquia federal;

IlI - excesso ou insuficiência de pessoal no quadro de origem ou no de desino.

\section{CAPÍTULO IV}

\section{Da Substituição}

Art. 39 - Haverá substituiçāo nos afastamentos do tilular de cargo de direção ou de função de chefia.

Parágrafo único - A substituição será remunerada qualquer que seja a natureza do afastamento, por periodo igual ou superior a cinco dias.

\section{CAPÍTULO V}

\section{Da Vacância}

Art. 40 - A vacância de cargo público decorrerá de:

$$
\begin{aligned}
& \text { l - recomendação; } \\
& \text { II - promoção; } \\
& \text { III - Iransferência; } \\
& \text { IV - readaptação; } \\
& \text { V - exoneração; } \\
& \text { VI - demissão; } \\
& \text { VII - aposentadoria; } \\
& \text { VIII - falecimento. }
\end{aligned}
$$

$\S 10$ A exoneraçāo dar-se-á a pedido ou ex officio.

\$ 2: A exoneração ex officio dc cargo de provimento efetivo somente se dará quando não satisfeitas as condiçōes do estágio probatório e nāo couber a recondução.

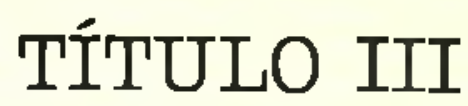

\section{Direitos e Vantagens}

\section{Do Vencimento}

Art. 4I - Vencimento é a retribuj- 
ção pelo exercicio de cargo público, de acordo com padrôes fixados $\mathrm{cm}$ lei.

Art. 42 - Remuneraçāo é o vencimento acrescido das vantagens de caráter permanente ou a ele incorporáveis, na forma previsı $\mathrm{cm}$ lei.

Ar1. 43 - O funcionário, investido em cargo em comissāo da Uniāo, Territórios e autarquias federais, deixará de perceber o vencimento do cargo efetivo, salvo direito de opção, fazendo jus à retribuiçāo do cargo em comissāo, acrescida das vantagens de caráter permanente inerentes ao cargo efelivo.

Parágrafo único - No caso de invesridura em cargo em comissāo de órgāo ou entidade diversa, as vantagens de caráter permanente serão pagas pelo órgāo de arigem.

Art. $44-O$ funcionário poderá ser posto à disposição de Fstado, Municipio, Distrito Federal, autarquia, sociedade de cconomia mista, empresa pública, fundação criada pelo poder público ou organismos internacionais com os quais o Brasil coopere, com ou sem remuneração, na forma e condiçōes estabelecidas em regulamento.

Art. 45 - O funcionário perderá:

1 - um terço da remuneraçāo quando afastado do exercicio do cargo por motivo de prisāo preventiva, pronúncia por crime comum ou funcional, ou denúncia recebida por crjme inafiançável, ou $\mathrm{cm}$ processo no qual nāo haja pronúncia, com direjio a ressarcimento dos descontos havidos, se absolvido;

II - metade da remuneração correspondente aos dias de suspensão disciplinar ou prisāo administrativa;

111 - dois terços da remuneraçāo durante o periodo de afastamento resultante de condenaçāo, por sentença definitiva, que nāo implique perda do cargo.

Arr. $46-O$ vencimento, a remuneração $c$ os proventos nāo sofrerão desconto além do previsto em lei, salvo indenização ou restituiçāo à Fazenda Pública ou à autarquia, nem serão objeto de arresto, seqüestro ou penhora, excelo o caso de prestaçāo de alimentos resultante de homologação ou decisāo judicial.

$\S 1$. A indenização ou a restituiçāo será descontada em parcelas men- sais não excedentes da décima parte do valor da remuneração.

$\S 2$. O disposto no parágrafo anterior nâo se aplica a funcionário exonerado ou demitido, ou que tiver cassada sua aposentadoria ou disponibijidade, hipótese em que o débito scrá quitado no prazo de até sessenta dias.

\section{CAPÍTULO II}

\section{Das Vantagens}

Art. 47 - Além do vencimento, podem ser pagas ao funcionário as seguintes vantagens, na forma estabelecida em regulamento:

I - indenizaçōes;

II - auxilios pecuniários;

111 - gratificaçōes.

§1: As indenizaçōes e os auxilios não se incorporam ao vencimento ou provento, para qualquer efeito, nem ficam sujeitos a imposto ou contribuiçāo previdenciária.

$\S 2^{\circ}$ As gratificaçōes podem incorporar-se ao vencimento ou provento, nos casos e condiçōes indicados em leí.

\section{SEÇÃO I Das Indenizaçōes}

Art. 48 - As indenizações ao funcionário compreendem:

l - ajuda de custo;

II - diária;

III - transporte.

Art. 49 - A ajuda de custo, como compensaçāo das despesas de viagem e instalaçāo, é devida ao funcionário que, no interesse do serviço, passa a ter exercicio em nova sede.

$\S 1$. Correm por conta do Poder Público as despesas com o transporte do funcionário e de sua familia, que compreendem passagem, bagagem e mobiliário.

$\S 2$. À familia do funcionário que vier a falecer, na situaçào prevista neste artigo, sāo assegurados ajuda de custo e transporte para a localidade de origem, dentro do prazo de um ano da remoção.

Art. 50 - A ajuda de custo é calculada sobre a remuneraçāo do cargo efetivo ou do cargo em comissão.

Parágrafo único - A ajuda de custo nāo exccderá à importância correspondente a três meses da remuneraçāo, salvo quando a mudança de sede obrigar o deslocamento para fora do Pais.

Art. 51 - Nāo serāo concedidos transporte e ajuda de custo, pelo órgāo de origem, ao funcionário que se afastar do cargo ou o reassumir em virtude de mandato eletivo.

Art, 52 - Ficam assegurados transporte ajuda de custo, inclusive no retorno, àquele que, nāo sendo funcionário da Uniāo ou de autarquia federal, for nomeado para cargo em comissāo com mudança de domicilio.

Art. 53 - O funcionário restituirá a ajuda de custo:

I - quando não se deslocar para a nova sede no prazo legal;

II - quando retornar ou pedir exoneração antes de completar cento e oitenta dias de excrcicio na nova scde.

Parágrafo único - Nāo haverá obrigaçāo de restituir no caso de exoneraçāo ex officio e de retorno decorrente de doença comprovada por laudo médico, ou de interesse do serviço.

Art. 54 - O funcionário que, a serviço, se deslocar da sede, em caráter eventual e transitório, fará jus a diárias compensatórias das despesas de pousada, alimentaçāo e locomoção.

Art. 55 - Conceder-se-á indenização de transporte ao funcionário que realizar despesas em serviços externos, por força das atribuiçōes normais de seu cargo.

Art. 56 - O valor das indenizaçōes e as condiçōes para sua concessāo serão estabelecidos em regulamento.

\section{SEÇĀO II Dos Auxilios}

Art. 57 - Serāo concedidos ao funcionário ou à sua familia os se. guintes auxílios pecuniários: 
I - auxílio-saúde;

II - auxilio-funeral;

111 - auxílio-familia;

IV - auxílio-natalidade.

Art. 58 - $\mathrm{O}$ auxílio-saúde é devido ao funcionário licenciado por motivo de acidente em serviço, doença profíssional ou moléstia grave, especificadas em lei.

Parágrafo único - $\mathrm{O}$ auxílio será concedido após cada seis meses consecutivos de licença, até o máximo de vinte e quatro meses, em importância equivalente a um mês da remuneraçāo do cargo.

Art. 59 - O auxilio-luneral será pago à família do funcionário falecido, ainda que aposentado ou em disponibilidde, em valor equivalente a um mês da remuneração ou proventos.

§ 1. Em caso de acumulaçāo legal, $\Theta$ auxilio será devido em razāo do cargo de maior remuneração ou proventos.

$\$ 20^{\circ}$ O auxílio será pago, também, ao funcionário por falecimento do cônjuge e de filhos menores ou inválidos.

§ 3: O auxílio será pago no prazo de quarenta e oito horas, e não será inferior a duas vezes o menor valor da escala de vencimentos.

Art. 60 - Quando o enterro nāo for custeado pelo funcionário ou pessoa da familia, o auxilio-funeral será pago a quem o tiver providenciado, pelo valor da despesa efeluada, observadas as normas estabelecidas no artigo anterior.

Art. 61 - O auxílio-famillia é devido por dependente do funcionário ou do inativo.

Art. 62 - Não será devido o auxílio-familia quando o dependente passar a perceber qualquer rendimento, em importância igual ou superior à do salário-mínimo.

Art. 63 - $\mathrm{O}$ auxilio-natalidde é devido à funcionária gestante, por motivo de parto, em quantia equivalente a duas vezes o menor valor da escala de vencimentos do funcionário civil da Uniāo.

$\S$ 1? Na hipótese de parto múltiplo, o auxílio ficará limitado a duas vezes a quantia estipulada neste artigo.

$\S 2$. Não sendo a parturiente funcionária, o auxílio é devido ao cônjuge funcionário.

\section{SEÇÃO III Das Gratificaçōes}

Art. 64 - Poderão ser concedidas ao funcionário, nos termos do regulamento, as seguintes gratificações:

$$
\begin{aligned}
& \text { I - de função; } \\
& \text { II - de representação; } \\
& \text { III - pela participaçāo em ór- } \\
& \text { gão de deliberaçāo coleti- } \\
& \text { va; } \\
& \text { IV - pela prestaçāo de serviço } \\
& \text { extraordinário; } \\
& \text { V - por tempo de serviço; } \\
& \text { Vl - de incentivo funcional; } \\
& \text { Vll - natalina. }
\end{aligned}
$$

Art. 65 - A gratificação por serviço extraordinário é devida por hora de trabalho prorrogado ou antecipado, na mesma razão percebida pelo funcionário por hora de trabalho normal, não podendo exceder de duas horas diárias.

Parágrafo único - Em se tratando de serviço noturno, o valor da hora extra é acrescida de vinte e cinco por cento.

Art. 66 - A gratificaçāo por tempo de serviço é devida à razāo de um por cento por ano de serviço público efetivo, incidente sobre o vencimento do cargo efetivo.

Art. 67 - O Poder Executivo instituirá os seguintes incentivos funcionais:

I - prêmios pela produção de idéias ou de trabalhos que favoreçam o aumento da produtividade e a reduçāo dos custos operacionais;

II - retribuiçāo adicional com pensatória:

a) de dedicaçāo exclusiva às atividades didáticas, de pesquisa científica ou tecnológica:

b) de conclusão de cursos de especialização, aperfeiçoamento e de outros relacionados com a carrejra.

III - diploma de honra ao mérj10, condecoraçã̃o e elogio.

Art. 68 - A gratificação natalina corresponderá a um doze avos da remuneraçāo devida em dezembro, por mês de serviço no respectivo ano.

Parágrafo único - A fraçāo igual ou superior a quinze dias será havida como mês integral.

Art. 69 - O funcionário exonerado perceberá a gratificação natalina proporcionalmente aos meses de serviço, calculada sobre a remuneraçāo do mês anterior ao da exoneração.

Parágrafo único - No caso de demissão ou da exoneração prevista no artigo $40, \S 2$., o funcionário não เerá direito à gratificação.

Art. 70 - A gratificação natalina é extensiva ao inativo e será paga no mês de dezcmbro de cada ano, comando-se por base o valor dos proventos devidos nesse mês.

Art. 71 - A gratificaçāo natalina não será considerada no cálculo de qualquer vanıagem pecuniária.

\section{CAPÍTULO III}

\section{Das Férias}

Art. 72 - O funcionário faz jus, anualmente, a trinta dias consecutivos de férias, que podem ser acumuladas até o máximo de dois períodos, no caso de necessidade do serviço.

$\S 1$ ?. Para o primeiro período aquisitivo, scrão exigidos doze meses de exercício.

$\$ 2$ : É vedado levar à conta de férias qualquer falta ao serviço.

Art. 73 - É facultada a conversâo em dinheiro de um rerço das férías, a requerimento do funcionário.

Art. 74 - As férias somente poderāo ser interrompidas por motivo de calamidade pública, comoçāo interna, convocação para o juri, servico militar ou eleitoral.

\section{CAPÍTULO IV}

\section{Das Licenças}

\section{SEÇÃO ] Disposiçōes Gerais}

Art. 75 - Conceder-se-á, nos termos e condiçōes de regulamento, licença: 
1 - para tratamento de saúde;

II - por motivo de doença em pessoa da familia;

II] - à gestantc e ao funcionário adotante;

IV - para o serviço militar;

$\mathrm{V}$ - por motivo de afastamento do cônjuge;

VI - para atividades políticas;

VII - especial;

VIII - para tratar de interesses particulares;

IX - para o exercício de mandato classista.

§ 1: O funcionário nāo poderá permanccer em licença da mesma espécie por periodo superior a vinte e quatro meses, salvo nos casos dos itens IV, V, VI e IX deste artigo.

$\S 2{ }^{\circ}$ A licença concedida dentro de sessenta dias do término de outra da mesma espécie é considerada como de prorrogaçāo.

\section{SECÄO II \\ Da Licença para Tratamento de Saúde}

Art. 76 - A licença para tratamento de saúde será concedida sem prejuizo da remuneraçāo do cargo.

Art. $77-\mathrm{O}$ funcionário, que apresentar indicios de lesões orgânicas ou funcionais, causadas em virtude de exposiçāo, em serviço, a raios$X$ ou subsrâncias radioativas, será afastado de imediaro do trabalho.

Parágrafo único - De acordo com - grau das lesōes, a autoridade competente poderá atríbuir ao funcionário tarefas sem risco de radiaçāo, ou licenciá-lo, conforme recomendaçāo de junta médica oficial.

Art. $78-\mathrm{O}$ exercicio de atividade remunerada durante o período de licença constîtui falta grave.

Art. 79 - O dano física ou menral sofrido pelo funcionário e que se relacione, mediata ou imediatamentc, com o exercício do cargo, configura acidente em serviço.

Ar1. 80 - Equipara-se ao acidenle em serviço:

I - a dano decorrente de agressão sofrida e não provocada pelo funcionário no exercicio do cargo ou funçāo.

II - o sofrido no percurso da residência para o Irabalho ou vice-versa.
Art. 81 - O funcionário acidentado em serviço, que necessite de rsatamento especializado nāo atendível pela cobcriura médico-assistencial, será tratado em instituiçāo indicada por junta médica oficial, à conta dos cofres públicos.

\section{SEÇĀO III \\ Da Licença por Motivo de Doença em Pessoa da Família}

Art. 82 - O funcionário poderá obter licença por moljvo de doença em ascendente, descendente, colateral ou afim, até o segundo grau civil, ou no cônjuge do qual nāo esteja legalmente separado.

$\$ 1$. A licença somente será concedida se a assistência direta do funcionário for indispensável e não puder ser prestada simultaneamente com o desempenho do cargo.

$\S 2$. A licença dependerá de inspeção por junta médica oficial e será concedida com a remuneraçāo do cargo efetivo até doze meses e, excedendo esse prazo, com dois terços dessa remuneraçāo, até vinte e quairo meses.

\section{SEÇÃO IV Da Licença à Gestanle}

Arr. 83 - Será concedida licença à funcionária gestante, por qua1ro meses, sem prejuizo da remuneraçāo do cargo.

$\S 1$. A licença será precedida de inspeção médica e terá início no primero dia do oitavo mês de gestação, salvo recomendaçāo em contrário.

$\S 2$. No caso de nascimento prematuro, a licença terá inicio a parrir do dia do parto.

$\$ 3$. Terminada a licença, a funcionária poderá ter sua jornada de trabalho reduzida, para amamentaçảo de filho de até aito meses de idade.

$\S 4$. No caso de natimorto, decorridos trinta dias do evento, a funcionária será submetida a exame médico $e_{1}$ se julgada apta, reassumirá o exercício.

Art. 84 - Em caso de adoçāo de criança de até cinco anos de idade ao funcionário adotante serâo concedi- dos sessenta dias de licença remunerada.

\section{SEÇÃO $\mathrm{V}$ \\ Da Licença para o Serviço Militar}

Art. 85 - Ao funcionário convocado para o serviço militar será concedida licença, na forma e condiçōes previstas na legislaçāo específica.

Parágrafo único - Concluido o serviço, o funcionário terá trinta dias para reassumir o exercício do cargo.

\section{SEÇĀO VI \\ Da Licença por Motivo de Afastamento do Cônjuge}

Art. 86 - O funcionário terá direito à licença, sem remunerçaão, para acompanhar o cônjuge removido ou transferido para outro ponto do território nacional ou para o exterior, ou eleito para exercer mandato eletivo.

Parágrafo único - Existindo, no novo local de residência, órgāo público ou autarquia federal, o funcionário nele terá exercicio, enquanto perdurar aquela situação.

\section{SEÇĀO VII \\ Da Licença para Atividade Política}

Art. 87 - O funcionário terá direito à licença sem remuncraçāo durante o periodo que mediar entre a sua escolha, em convenção partidária, como candidato a cargo eletivo, e a véspera do registro de sua candidatura perante a Justiça Eleitoral.

Parágrafo único - A partir do registro de sua candidatura e até o décimo-quinto dia seguinte ao da eleiçảo, o funcionário fará jus à licença com a remuneração do cargo efetivo, como se em exercício estivesse.

\section{SEÇĀO VIII Da Licença Especial}

Art. 88 - Após cada qüinqüênio de efetivo e inintcrrupto exercício no serviça público, o funcionário fará jus à licença especial de 1 rês meses, com a remuneração do cargo de provimen- 
Io efetivo.

Art. 89 - Nāo se concederá licença especial se houver o funcionário, em cada qüinqüênio:

I - sofrido pena de suspensão;

11 - faltado ao serviço, injustifjcadamente;

III - gozado licença salvo nas hipóteses de tratamento da própria saúde, de gestante e do funcionário adotante.

Parágrafo único - A licença para tratamento da própria saúde suspende a contagem do periodo aquisitivo.

\section{SEÇÃO IX \\ Da Licença para Tratar de Interesses Particulares}

Art. 90 - A critério da Adminis tração, poderá ser concedida ao funcionário estável licença para tratar de interesses particulares, pelo prazo de um ano, prorrogável pelo mesmo período, sem remuneração.

Parágrafo único - A licença poderá ser interrompida a qualquer tempo, a pedido do funcionário ou a cri tério da Administração.

\section{SEÇÃO X \\ Da Licença para o Exercício de Mandato Classista}

Art. 91 - O funcionário terá direito à licença para desepenhar mandato eletivo em confederaçāo, federação de servidores públicos ou associaçāo de classe de âmbilo nacional, com remuneraçāo do cargo efetivo.

$\S 1$ : A licença terá a duração do mandato, prorrogável no caso de reeleição e por uma única vez.

§ 2: O afastamento será restrito ao máximo de quatro dos mandatários.

\section{CAPÍTULO V}

\section{Do Tempo de Serviço}

Art. 92 - O tempo de serviço público federal, em que se inclui o pres. tado às Forças Armadas, é contado para todos os efeitos.

Parágrafo único - O tempo de serviço relativo a Tiro-de-Guerra só é computável para aposentadoria e disponibilidade.

Art. 93 - O tempo de serviço Distrital, estadual, municipal, e o prestado às respectivas autarquias, é computado para aposentadoria, disponibilidade e uniênio.

Art. 94 - A apuração do tempo de serviço será feita em dias, convertidos em anos, à razāo de trezentos e sessenta e cinco dias por ano, salvo quando bissexto.

Parágrafo único - É vedada a averbação do tempo de serviço, a que se refere o artigo anterior, junto à Uniāo e suas autarquias, com quaisquer acréscimos ou em dobro, salvo se houver dispositivo correspondente na legislação federal.

Art. 95 - Serão considerados como de efetivo exercício os afastamentos em virtude de:

1 - férias;

11 - casamento ou luto;

III - exercicio de cargo em comissão ou equivalente em entidade pública, empresa pública, sociedade de economia mista e fundaçāo instituída pelo Poder Público;

IV - exercício de funçāo ou cargo de governo ou administraçāo, em qualquer parte do território nacional, por nomeaçāo do Presidente da Re pública;

V - convocaçāo para o serviço militar;

VI - juri e outros serviços obrigatórios por lei;

VIl - desempenho de mandato elerivo federal, estadual ou municipal;

VIIJ - licença especial;

IX - licença à funcionária gestante, ou ao funcionário adotante, na hipótese do artigo 84 ;

$\mathrm{X}$ - Iicença ao funcionário acidentado em serviço ou acometido de doença profissional:

XI - missāo ou estudo no País ou no estrangeiro, quando autorizado o afastamento;

XII - licença para tratamento da própria saúde, observado o disposto no parágrafo único do artigo 89 ;

XIII - licença para atividade política de que trata o parágrafo único do artigo 87, exceto para promoção; XIV - licença para o exercicio de mandaro classista, exceto para promoçāo e licença especial;

XV - participaçāo em programa de treinamento regularmente instituído;

XVI - doença de notificaçāo compulsória, inclusive em pessoa da familia

Art. 96 - Contar-se-á para efeito de aposentadoria e disponibilidade o tempo de:

I - licença para tratamento da saúde de pessoa da familia;

II - licença para atividade polítjca, na forma do artigo 87, coput;

III - descmpenho de mandato eleivo federal, estadual ou municipal anterior ao ingresso no serviço públi$\mathrm{co}$;

IV - serviço em atividade priva$\mathrm{da}$, vinculada à Previdência Social.

Parágrafo único - $\mathrm{O}$ tempo em que o funcionário esteve em disponibilidade ou aposentado será considerado, exclusivamente, para nova aposentadoria ou disponibilidade.

\section{CAPÍTULO VI}

\section{Das Concessões}

Art. 97 - Sem qualquer prejuizo poderá o funcionário ausentar-se do serviço:

I - por um dia, para registro de filho ou doaçāo de sangue;

1] - alé oito dias conseculivos, por motivo de:

a) casamento;

b) falecimento do cônjuge, pais e filhos.

Art. 98 - Atendida a conveniência do serviço, poderá ser concedido horário especial ao funcionário estudante, quando comprovada a incompatibilidade entre o horário escolar e o da repartiçāo.

Art. 99 - Ao funcionário estudante, que mudar de sede no interesse da Administraçāo, é assegurada matrícula em instituiçāo de ensino congênerc, situada na localîdade da nova residência ou na mais próxima, 
na forma e condiçôes estabelecidas na legislaçāo específica.

Parágrafo único - $\mathrm{O}$ disposto nesre artigo esiender-se-á ao cônjuge e aos filhos que vivam nа companhia do Tuncionário, bem como aos menores sob sua guarda, com autorizaçāo judicial.

\section{CAPÍTULO VII}

\section{Do Direito de Petição}

Art. $100-\hat{E}$ assegurado ao funcionário o direilo de requerer e de representar.

Parágralo único - O requerimen[o é cabivel, para defesa de direito ou de interesse legitimo, e a representa çào, contra abuso de autoridade ou desvio de poder.

Art. $101-$ O requerimento será dirigido à autoridade competente em razão da matéria, e por intermédio daquela a que o funcionário estiver inediatamente subordinado.

Parágrafo único - A representaçâo, encaminhada pela via hicrárquica, será obrigatoriamente apreciada pela autoridade superior àquela conIra a qual é interposta.

Art. 102 - Cabe pedido de reconsideração dírigido à autoridade que houver expedido o ato ou proferido a primeira decisāo.

Parágrafo único - É de quinze dias, contados a partir da ciência do ato ou da decisão, o prazo para apresenlaçāo de pedido de reconsideraçāo.

Art. 103 - O requerimento e o pedido de reconsideração devem ser despachados no prazo de cinco dias e decididos deriro de 1rinta.

Art. 104 - Cabe recursos:

1 - do indefcrimento do pedido de reconsideração;

II - das decisōes sobre os recursos sucessivamentc interpostos.

\$ l." O recurso é dírigido à autoridade imediatamente superior à que liver expedido o ato ou proferido a decisảo recorrida.

$\S 2$ : O recurso é interposto por in- lermédio da autoridade recorrida, que pode reconsiderar a decisâo, ou, mantendo-a encaminhá-la à autoridade superior.

$\S 3$ ?. É de 1rinta dias o prazo para interposiçāo de recurso, a contar da publicaçâo ou ciência, pelo interessado, da decisāo recorrida.

$\$ 4$. O recurso será decidido no prazo de trinta dias.

Art. 105 - Ao pedido de reconsideraçâo e ao recurso, poderá, a autoridade recorrida, dar efeito suspensivo.

Art. 106 - O direito de petiçāo prescreve:

I - em cinco anos, quanto aos atos de demissāo, cassaçāo de aposentadoria ou disponibilidade e aos referentes à maléria patrimonial;

II - em cento e vinte dias nos demaís casos, salvo quando outro prazo for estabelecido em lei.

Art. 107 - O prazo de prescriçāo contar-se-á da data da publicaçāo oficial do ato impugnado ou da data da ciência pelo interessado, com prevalecência da que primeiro ocorrer.

Art. 108 - O pedido de reconsideraçāo e o recurso, quando cabiveis, interrompem a prescrição.

Parágrafo único. Interrompida a prescriçāo, o prazo recomeçará a correr pelo restante, desde que nāo inferior à metade do prazo original, no dia $\mathrm{cm}$ que cessar a interrupçâo.

Art. $109-O$ ingresso em juizo não implica necessariamente suspensão, na instância administrativa, de pleito formulado pelo funcionário.

Ar1. 110 - Para o exercício do direito de periçāo, será assegurada vista de processo ou documento, na reparliçāo, ao funcionário, a advogado ou a mandatário especialmente constituído.

\section{CAPÍTULO VIII}

\section{Da Disponibilidade}

Art. 111 - Extinto o cargo ou declarado sua desnecessidade, o funcio- nário estável licará em disponibilidde, com proventos proporcionais ao tempo de serviço.

Ar1. 112 - O Poder Público providenciará o aprovejtamento do funcionário em disponibilidade no prazo máximo de cento e oitenta dias:

I - em oulro cargo de natureza e vencimento compativeis com o que ocupava;

II - ocorrendo uma das hipóteses previstas nos incisos II e Ill do arcigo 38;

III - no antigo cargo, se restabelecido, ainda que modificada sua denominaçāo.

Art. $113-\mathrm{O}$ funcionário em disponibilidde, atendidos os pressupostos legais, poderá ser aposentado.

\section{CAPÍTULO IX}

\section{Da Aposentadoria}

Art. 114 - $\mathrm{O}$ funcionário será aposentado:

I - por invalidez:

II - compulsoriamente, aos setenta anos de idade;

III - voluntariamente, ao completar:

a) trinta e cinco anos de serviço, se do sexo masculino;

b) trinıa anos de serviço, se do sexo feminino;

c) trinta anos de efetivo exercicio em funçōes de magistério, se professor;

d) vinte e cinco anos de elecivo exercicio em funçōes de magistério, se professora.

Art. 115 - Serāo integrais os proventos da aposentadoria:

I - voluntária, por tempo de serviço;

II - por invalidez decorrente de acidente em serviço, molésila profissional ou doença grave, prevista em lei, com base nas conclusōes da medicina especializada.

Parágrafo único - Fora das hipóteses previstas neste artigo, os provenlos da aposentadoria serāo proporcionais ao tempo de serviço. 
Art. 116 - A aposentadoria compulsória será automática e declarada por ato com vigência a partir do dia em que o funcionário atingir a idade. limite.

Art. [17 - $\mathbf{A}$ aposentadoria por invalidez será precedida de licença para tratamento de saúde, por periodo пão excedente a vinte e quatro meses.

$\S$ 1. Após o período da licença, e nẫo estando ern condiçōes de assumir, desde logo, o cargo, ou de ser readaptado em outro mais compativel com a sua capacidade fisica ou mental, o funcionário será aposentado provisoriamente.

$\S 2$. A aposentadoria, na hipóte se do parágrafo anterior, será precedida de perícia, realizada por junta médica oficial.

\$3. A perícia será renovada anualmente, dentro do prazo de cinco anos da aposentadoria, a fim de ser verificada a coveniência de readapraçāo ou reversão do funcionário.

$\$ 4$. Transcorrido o prazo a que se rcfere o parágrafo anterior, a aposentadoria será considerada definitiva.

$\S 5$. O lapso de tempo compreen dido entre o término da licença c a publicação do ato de aposentadoria será considerado como de prorrogação da licença.

Art. $118-O$ funcionário que contar tempo de serviço sufíciente para se aposentar voluntariamente passa rá à inatîvidade:

l - com o vencimento do cargo em comissão ou a retribuição da função gratificada que houver exercido em qualquer época, por, no mínimo, cinco anos ininterruptos;

II - com iguais vantagens, desde que o exercício referido no inciso anterior tenha compreendido um período de, pelo menos, dez anos, consecutivos ou nâo.

$\S 1$. Quando mais de um cargo ou funçāo haja sido exercido, serão atribuídas as vantagens do de maior valor, desde que Ihe corresponda um exercício não inferior a dois anos; fora dessa hipótese, atribuir-se-ão as vantagens do de valor imediatamente inferior dentre os exercidos.

$\S 2$. Os valores dos vencimentos de cargos de natureza especial, previstos $\mathrm{cm}$ lei, e das funçōes de direçāo ou cheflia, e de assessoramento ou assistência, serão considerados para os efeitos deste artigo.
Art. 119 - O cálculo dos proventos da aposentadoria terá por base o vencimento mensal do cargo efetivo, acrescido das vantagens incorporáveis por lei.

Art. $120-$ Os proventos da aposentadoria serão revistos a partir da mesma dara e cm igual proporção, sempre que modificados os vencimentos dos funcionários em atividade, transformado ou reclassificado o cargo em que se deu a aposentadoria.

Parágrafo único - $\mathrm{O}$ aposentado com proventos proporcionais, se acometido de moléstia grave especiricada em lei, passará a ter proventos integrais.

Art. 121 - Os proventos da aposentadoria ou disponibilidade, quando proporcionais ao tempo de serviço, nâo serāo in feriores ao menor valor da escala de vencimentos do funcionalismo civil da União.

\section{CAPÍTULO $\mathrm{x}$}

\section{Da Previdência e Assistência}

Art. 122 - A União instituirá planos especiajs de previdência e assistência ao funcionário e à sua família.

\section{TÍTULO IV \\ Do Regime Disciplinar}

\section{CAPÍTULO I}

\section{Dos Deveres}

Art. 123 - Além do exercício das atribuiçōes do cargo, são deveres do funcionário:

1 - guardar leaidade às instiruiçōes constitucionajs e adminisı rativas a que servir;

II - observar as normas Iegaîs e regulamenlares;

III - cumprir as ordens superiores, exceto quando manifestamentc ilegais;

IV - atender prontamente:

a) ao público em geral;

b) à expediçāo de certidôes requeridas para a defesa de direito e esclarecimentos de situaçōes;

c) às requisicōes para a defésa da Fazenda Pública;

$\mathrm{V}$ - levar ao conhecimento da autarquia superior as irregularidades de que tiver ciência em razão do cargo;

VI - zelar pela economia e conservaçāo do patrimônio público;

Vll - guardar sigilo sobre os assuntos da repartiçāo;

VIII - manter comportamento discreto;

IX - ser assiduo;

$X$ - ser pontual;

XI - proceder com urbanidade.

\section{CAPÍTULO II}

\section{Das Proibições} bido:

Art. 124 - Ao funcionário é proj-

I - referir-se, de modo depreciativo ou desrespeitoso, em requerimen10, representaçâo, parecer ou despacho ou qualquer outro expediente, à autoridade, a funcionário e usuários, bem como a atos do Poder Público;

IJ - retirar, sem prévia anuência da autoridade competente, qualquer documento ou objern da repartição;

II] - promover manifestaçāo de apreço ou desapreço no recînto da repartiçāo:

IV - valer-se do cargo para lograr proveito pessoal ou de terceiro;

$\mathrm{V}$ - coagir ou aliciar subordinado com objetivo de natureza politicopartidária:

VI - participar de gerência ou ad- 
ministração de empresa privada ou, ainda, de sociedade civil prestadora de serviços ao Estado;

VII - exercer comércio ou participar de sociedade comercial, exceto como acionista, cotista ou comanditário;

VIll - pleitear, como procurador ou intermediário, junto às repartições públicas, salvo quando se tratar de interesse relacionado com benefícios assistenciais de parente consangüineo ou afim até o segundo grau civil;

IX - receber propinas, comissōes, presentes ou vantagens de qualquer espécie em razão de suas atribuiçōes:

$\mathrm{X}$ - cometer à pessoa estranha à repartiçāo, fora dos casos previstos em lei, o desempenho de encargo que the competir ou a seus subordinados;

XI - aceitar comissão, emprego ou pensão de Estado estrangeiro, sem autorização expressa do Presidente da República;

XII - praticar a usura sob qualquer de suas formas;

XIII - reter, injustificadamente, o andamento de processo.

Art. 125 - Somente do ponto de visıa doutrinário ou da organização do scrviço, em 1rabalho assinado, será lícito ao funcionário criticar atos do Poder Público.

\section{CAPÍTULO III}

\section{Da Acumulação}

Art. 126 - E vedada a acumulaçāo de cargos ou funçōes públicas, excelo:

l - a de um cargo de juiz com ourro de magistério superior;

II - a de dois cargos de professor;

Ill - a de um cargo de professor com outro técnico ou cientifico; ou

IV - a de dois cargos privativos de médico.

Parágrafo único - Em qualquer dos casos, deverão ser observados os requisitos de correlaçāo de matérias e compatibilidade de horários.

Art. 127 - A proibição do artigo anterior estende-se à acumulação de cargos da União com os dos Estados, Distrito Federal, Municipios, entidades autárquicas, empresas públicas e sociedades de economia mista.

Art. 128 - A proibição de acumular nāo se aplica aos aposentados, quanto ao exercício de mandato eletivo, quanto ao de um cargo em comissāo ou quanto a contrato para prestação de serviços técnicos ou especializados.

Art. 129 - Não se compreende na proibição de acumular a percepção conjunta de:

I - pensão com vencimento, remuneraçāo ou salário;

II - pensão com provento de disponibilidade, aposentadoria ou reforma;

III - proventos quando resultantes de cargos legalmente acumuláveis.

Art. $130-O$ funcionário nāo poderá exercer mais de um cargo em comissão ou funçāo de chefia, nem ser remunerado pela participação em mais de um órgão de deliberação coletiva.

\section{CAPÍTULO IV}

\section{Das Responsabilidades}

Art. 131 - O funcionário responde civil, penal e administrativamente pelo exercício irregular de suas atribuições.

Art. 132 - A responsabilidade civil decorre de ato omissivo ou comissivo, doloso ou culposo, que resulte em prejuízo à Fazenda Pública ou a terceiros.

\& 1. A indenízaçāo de prejuizo causado à Fazenda Pública, salvo no caso de dolo ou falta grave, poderá ser liquidada na forma prevista no $\$ 1$. do artigo 46 .

§ 2: Tratando-se de dano causado a terceiro, responderá o funcionário perante a Fazenda Pública, em açâo regressiva.

Art. 133 - A responsabilidade penal abrange os crimes e contravençōes imputados ao funcionário, nesta qualidade.
Art. 134 - A responsabilidade administrativa resulta de ato comissivo ou omissivo, praticado no desempenho do cargo ou função.

Art. 135 - As sanções civis, penais e disciplinares poderão cumular$\mathrm{se}$, sendo umas e outras independentes entre si.

Art. 136 - A absolvição criminal só afasta a responsabilidade civil ou administrativa se concluir pela inexistência do fato ou negar-lhe a autoria.

\section{CAPÍTULO V}

\section{Das Penalidades}

Art. $137-$ Sāo penas disciplinares:

I - repreensāo:

11 - suspensāo;

111 - demissão;

IV - cassação de aposentadoria ou disponibilidade.

Art. 138 - Na aplicaçāo das penas disciplinares, serāo consideradas a natureza e a gravidade da infraçāo cometida e os danos que dela provierem para o serviço público.

Art. 139 - A pena de repreensāo será aplicada por escrito, nos casos de inobservância de dever funcional previsto em lei, regulamento ou normas internas de serviço, e nos de desobediência à ordem superior, exceto quando manifestamente ilegal.

Art. 140 - A pena de suspensão, que não excederá de sessenta dias, será aplicada em caso de falta grave ou reincidência especifica.

Art. 141 - As penas de repreensão e de suspensão serāo canceladas após o decurso de três ou cinco anos de efetivo exercicio, respectivamente, se o funcionário não houver, nesse periodo, praricado qualquer nova infraçāo disciplinar.

Parágrafo único - O cancelamento da penalidade não surtirá efeitos retroativos.

Art. 142 - A pena de demissão será aplicada nos casos de:

I - crime contra a Administração Pública; 
11 - abandono de cargo;

III - inassiduidade habitual;

IV - incontinência pública e conduta escandalosa;

$\mathrm{V}$ - insubordinação grave em serviço;

Vl - ofensa física em serviço a funcionário ou particular, salvo em legitima defesa;

VII - aplicação irregular de dinheiro público;

VIII - revelação de scgredo que o funcionário conheça em razāo do cargo;

IX - lesão aos cofres públicos e dilapidaçāo do patrimônio nacional;

$\mathrm{X}$ - corrupçāo;

$\mathrm{XI}$ - transgressāo de quaisquer dos itens IV e XI do artigo 123;

XIl - acumulaçāo de cargo ou funçāo pública, quando comprovada a má fé.

§ 1: Considera-se abandono de cargo a ausência ao serviço, sem causa justificada, por mais de trinta dias consecutivos.

$\S 2$. Entende-se como inassiduidade habitual a falta ao serviço, sem causa justificada, por quarenta e cinco dias interpoladamente durante o periodo de doze meses.

Art. 143 - O ato de imposição de penalidade mencionará sempre o fundamenco legal e a causa da sanção.

$\S 1$ I. As penas de demissão, cassaçāo de aposentadoria ou de disponibilidade serāo aplicadas pela autoridade originariamente competente em cada caso, para nomear, aposentar ou colocar en disponibilidade o funcionário.

$\S 2$. As penas de repreensão e de suspensāo até trinta dias serāo aplicadas pelo dirigente do órgāo de pessoal.

Art. 144 - A aplicaçāo da pena de demissāo acarreta incompatibilidade com nova investidura em cargo público.

Parágrafo único - Transcorridos cinco anos do ato de demissão, o exfuncionário poderá pleitear sua reabilitação a ser procedida pela Administraçāo caso comprovada a inexistência, naquele lapso de tempo, de qualquer condura que desaconselhe o reingresso no Serviço Público.

Art. 145 - Será cassada a aposentadoria ou a disponibilidade do inativo que praticou, quando em acividade, falta punivel com demissão.
Art. 146 - Será cassada a disponibilidade quando o funcionário, nessa situaçāo, investiu-se ilegalmente em cargo ou funçāo pública, ou aceitou comissão, emprego ou pensão de Estado estrangeiro, scm prévia e expressa autorização do Presidente da República.

Parágra fo único - Será igualmente cassada a disponibilidade do funcionário que nāo assumir no prazo legal o exercício do cargo em que for aproveitado.

Art. 147 - Será punido com sus pensāo de até quinze dias o funcionário que, injustificadamente, se recusar a ser submetido à inspeçāo médica determinada pela autoridade competente.

Art. 148 - A açāo disciplinar prescreverá:

I - em cinco anos, quanto às infrações puniveis com demissāo e cassação de aposentadoria;

II - em dois anos, quanto à suspensão;

lll - em um mês, quanto à repreensāo.

$\S 1$. O prazo de prescrição começa a correr da data em que o ilícito foi praticado ou da de seu conhecimento pelo Poder Público.

$\S 2:$ Os prazos de prescrição previstos na lei penal aplicam-se às in frações disciplinares definidas, também, como crime.

§ 30. Interrompe-se a prescrição com a ahertura de sindicância ou instauração de processo administrativo disciplinar.

$\S 4$. Interrompido o curso da prescrição, recomeçará ele a correr, pelo prazo restante, a partir do dia em que cessar a interrupção.

\section{CAPÍTULO VI}

\section{Da Prisão Administrativa}

Art. 149 - A prisāo administrativa será aplicada ao responsável por dinheiro ou valores pertencentes à $\mathrm{Fa}$ - zenda Pública, ou que se acharem sob a guarda desta, no caso de alcance ou de omissāo em efetuar as entradas nos devidos prazos.

$\$ 1$ I. Compete ao Ministro de Es tado, aos Governadores dos Territórios, ao dirigente de órgāo integrante da Presidência da República, de autarquias e de repartiçōes da Administração Federal direta, ou autárquica, nos Estados, ordenar, fundamentalmente e por escrito, a prisão administrativa.

$\S 2$. A autoridade que ordenar a prisão adminisı́rativa comunicará, de imediato, o fato ao juiz competente, e determinará a tomada de contas do responsável.

§ 3: A prisão administrativa não excederá de noventa dias e será revogada tāo-Jogo o acusado haja ressarcido o dano ou oferecido garantia idônea.

§ 4. Reconhecida sua inocência, o funcionário terá direito à diferença de rcmuneraçāo e à contagem, para todos os efeitos, do periodo correspondente à prisão administrativa.

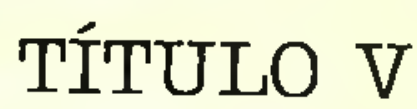

$$
\begin{gathered}
\text { Do Processo } \\
\text { Disciplinar e sua } \\
\text { Revisão }
\end{gathered}
$$

\section{CAPÍTULO I}

\section{Do Processo}

Art. 150 - A autoridade, que iiver ciência de irregularidade no serviço público, é obrigada a promoverthe a apuraçāo imediata, assegurando-se ao acusado ampla defesa.

Art. 151 - Coma medida preparatória, a autoridade deverá apurar, sumariamente, at ravés de sindicância, a irregularidade de que tiver conho. cimento. 
Art. 152 - O processo disciplinar precederá aplicaçāo das penalidades de suspensão, por mais de trinta dias, demissão e cassação de aposentadoria ou disponibilidade.

Ar1. 153 - O processo será conduzido por comissão composıa de três funcionários estáveis, designados pela autoridade responsável pela sua instauraçāo, a qual indicará, dentre eles, $\mathrm{c}$ respectivo presidente.

Parágrafo único - $\mathrm{O}$ presidente da comissão designará funcionário para servir de secretário.

Ar1. 154 - Nāo poderá participar de comissão de sindicância ou de inquérito, mesmo como secretário, parente do denunciante ou do denunciado, consangüineo ou afim, em linha reta ou colateral, até o terceiro grau.

Arı. 155 - Serāo objcio de apuraçāo as denúncias formuladas por escrito e que contenham identificação do denunciante.

Art. 156 - O processo disciplinar instaura-se-á através de inquérito administrativo, que compreenderá:

1 - sindicância, nos termos do arligo 151;

II - instrução;

111 - citaçāo do indiciado e tipificação do ilicito;

IV - defesa cscrita do indiciado;

$\mathrm{V}$ - relatório conclusivo da co- missão com apresentação do processo à autoridade julgadora;

VI - decisāo.

Art. 157 - A Comissão, scmpre que necessário, dedicará 1odo o tempo aos trabalhos do inquérito, ficando seus membros, em tais casos, dispensados do serviço alé a entrega do relatório.

Art. $158-O$ prazo de duração do inquérito será de sessenta dias, prorrogável por igual periodo, pela autoridade que houver determinado a instauraçảo do processo.

Ar1. 159-A comissão procederá a todas as diligências cabiveis, recorrendo, quando necessário, a técnicos ou peritos, com vistas à completa instruçāo do processo.

$\S 1$. As partes serāo intimadas para todos os atos, assegurado a elas o direito de parlicipação na produção de provas, mediante requerimento de perguntas às testemunhas e formulação de quesitos, quando se tratar de prova pericial.

§ 2. O presidente da comissão de inquérito poderá denegar pedidos manifestamente protelatórios ou de nenhum interesse para o esclarecimento dos fatos, justificando a sua decisāo.

Ar1. 160 - Ultimada a ins1rução, proceder-se-á a cullacāo do indiciado para, no prazo de dez dias, apresentar sua defesa cscrita, assegurada vista prévia do processo na repartição.

\& 1. Havendo dois ou mais indiciados, o prazo será comum e de vinte dias.

$\S 2$. Achando-se o indiciado em Iugar incerto c não sabido, será cíado por edital, com prazo de quinze dias.

\$3. O prazo de defesa poderá ser prorrogado pelo dobro, para diligências reputadas imprescindiveis.

Ar1. 16] - Para defender o indiciado revel, será designado ex officio funcionário de formação superior, de preferência.

Art. 162 - Decorrido o prazo de defesa, a comissão elaborará relatório conclusivo e remelerá o processo à autoridade que o houver instaurado, indicando, se for o caso, a disposição lcgal transgredida e a pena aplicável.

Art. 163 - A autoridade instauradora proferirá decisāo em 1rinta dias, ou remeterá o processo à autoridade competente para decidir, den1ro de igual prazo.

§ 1. Não havendo decisâo no prazo deste artigo, 0 indiciado, se afastado nos termos do artigo 168 , reassumirá automaticamente o exercicio do cargo ou função.

\section{A VEZ DO SERVIDOR}

\section{Você também pode dar sua sugestāo ou, mesmo, saber como vai o Plano de Reforma Administrativa. É só escrever. Para sugerir ou perguntar.}

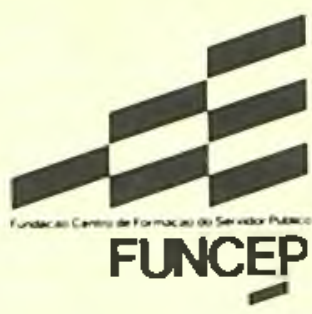

Setor de Áreas Isoladas Sul 70.610 - Brasilia - DF 
$\S 2 \circ$ Havendo mais de um indiciado e diversidade de sançōes, o julgamento caberá à autoridade competente para imposiçāo da pena mais grave.

Art. 164 - Quando os fatos apurados configurarem ilícito penal, remeter-se-á o processo ao órgão do Ministério Público, ficando traslado na repartição.

Parágrafo único $-\mathrm{Se}_{\text {, }}$ antes de instaurado ou concluido o processo, houver indício da prática de crime, a autoridade competente comunicará o fato à autoridade policial.

Art. 165 - No curso do processo administrativo, o acusado poderá acompanhar o feito pessoalmente, ou por intermédio de defensor.

Art. 166 - Assegurar-se-á trans. porte ao funcionário convocado a de por fora da sede de sua repartição.

Art. 167 - Só se concederá exo. neração ao indiciado após a conclusão do processo administrativo a que responder.

\section{CAPÍTULO II}

\section{Do Afastamento Preventivo}

Art. 168 - $\mathrm{O}$ afastamento preventivo será aplicado pela autoridade instauradora do processo, quando entender que a permanência do funcionário possa prejudicar a apuração dos falos.

Parágrafo único - O afastamento não excederá de cento e vinte dias e será revogado tāo-logo cessem os molivos que o determinaram.

\section{CAPÍTULO III}

\section{Da Revisão do Processo}

Art. 169 - A qualquer tempo, poderá ser requerida revisāo do proces so administrarivo, quando se aduzirem fatos ou circunsiâncias suscetiveis de justificar a inocência do requerente ou a inadequaçāo da pena aplicada.

Parágrafo único - Em caso de falecimento, incapacidade mental ou desaparccimento, qualquer pessoa da família poderá requerer a revisão do processo.

Art. $170-O$ pedido de revisāo será dirigido à autoridade que proferiu a decisão.

§1. A revisão correrá em apenso an processo originário, e será realizada, no prazo de noventa dias, por comissão composta de três funcionários estáveis, aplicando-se-lhe, no que couber, as disposiçōes concernentes ao processo administrativo.

§ 20. Sāo impedidos de integrar a comissāo revisora os funcionários que constituíram as de sindicância ou de inquérito.

Art. 17] - Da revisão não poderá resultar agravação da pena.

\section{TÍTULO VI \\ Disposições Gerais}

Art. 172 - O Dia do Funcionário Público será comemorado a 28 de ouuubro.

Art. 173 - Serāo contados por dias corridos os prazos previstos nesta lei.

Parágrafo único - Na contagem dos prazos, exclui-se o dia do começo $e$ inclui-se o do vencimento, ficando prorrogado para o primeiro dia útil seguinte o prazo vencido em dia em que nōo haja expediente.

Art. 174 - Por motivo de conviccấo filosófica, religiosa ou política, nenhum servidor poderá ser privado de qualquer de seus direitos, nem sofrer alteraçāo em sua afividade funcional.

Art. 175 - As disposicōes deste ESfoluto aplicam-se, subsidiariamente, às carreiras regidas por leis especiais.

Art. 176 - Consideram-se da família do funcionário, além do cônjuge efilhos, quaisquer pessoas que vivam às suas expensas e constem de seu assentamento individual.

Parágrafo único - Equipara-se ao cônjuge a companheira on compowheiro, com mais de cinco anos de vi da ell comum com o funcionário, ou, por menor prazo, se da uniäo houver prole.

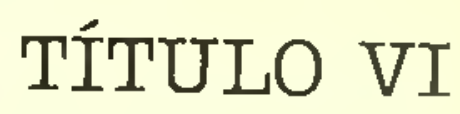

\section{Disposições Transitórias e Finais}

Art. $177-A$ inclusão no regìne deste Estaluta, dos aluais servidores regidos pelo legislação trahalhista, pertencentes aos órgāos da Uniâo, Territórios e autarquias, será objeto de lei especial.

Art. 178 - O presente Esialulo será regulameniado pelo Poder Executivo.

Parágrafo único - Alé a regula mentação prevista nesıe artigo, conti nuam em vigor os atuais regulamen tos no que näo for incompativel com os preceitos deste Estoluto.

Art. 179 - O Poder Execusivo, dentro do prozo de cento e oilento dias, submeterá ao Congresso Nocional projetos de leis fixando as diretrizes sobre:

$I$ - sisıemas de previdência e de as sistêncio ao funcionário:

11 - plano de classificaçāo de cargos e funções estruturado em carrejras, que possibilite ao funcionário accsso até o nivel da mais alta hierar quia profissional e the assegure o exercício de cargo cm comissāo ou funçāo de chefia;

III - plano de retribuiçāo de cargos e funçỏes, respeitadas as condi. ções do mercado de trabalho;

IV - plano de formaçāo c aperfeiçoamento do funcionário, inclusive para desempenho de cargos de provimento em comissão e funçōes de chefia.

Art. 180 - Esta Lei entrará em vīgor na data de sua publicaçāo, revogada a I ei n: 1.711, de 28 de outuhro de 1952, com suas alteraçōes e demais disposiçōes em contrário. 


\title{
VEJA AS DIFERENÇAS ENTRE O ANTEPROJETO E O ESTATUTO ATUAL
}

\author{
Diferenças básicas \\ entre o Estatuto atual
}

(Lei n. I.71l, de 28 de outubro de 1952)

e o anteprojeto do novo.

elaborado pela Comissão Intercameral.

\begin{tabular}{|c|c|c|c|}
\hline ESPECIFICAÇÃO & ESTATUTO ATUAL & ANTEPROJETO INTERCAMERAL & OHSERVACAO \\
\hline 1 Número de artigos & 272 & IBO & $\begin{array}{l}92 \text { arrigos a menos, ou seja, } \\
\text { uma reduçăo de } 1 / 3 \text { do lexlo } \\
\text { vigente. }\end{array}$ \\
\hline $\begin{array}{l}2 \text { Faixa etária para ingres- } \\
\text { so no Serviço Público } \\
\text { Federal }\end{array}$ & IB алов (алt. 22, II) & de 18 a 60 anos (art. 5?) & $\begin{array}{l}\text { Lei ordinária extravagante es- } \\
\text { Labeleceu a idade de so anos } \\
\text { como limite máximo para a } \\
\text { maioria dos casos. (Lei no. } \\
6.374 \text {, de } 31 / 05 / 76 \text {, alterada } \\
\text { pela Lei n. } 7.176 \text {, de } 15 / 12 / 83 \text { ). }\end{array}$ \\
\hline 3 Formas de Provimenio & 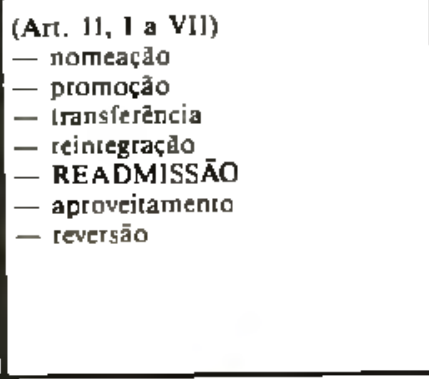 & $\begin{array}{l}\text { (Art. } 7 \% \text { I a VIII) } \\
\text { - nomeaçāo } \\
\text { - RECONDUÇĀO } \\
\text { - promoção } \\
\text { - transfrêncla } \\
\text { - READAPTACĀO } \\
\text { - reinlegraçāo } \\
\text { - reversāo } \\
\text { - aproveitamento }\end{array}$ & 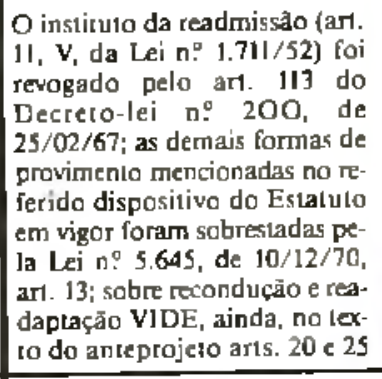 \\
\hline$\triangle$ Concurso Público & - & $\begin{array}{l}\text { garantia de nomeaçåo dos classi- } \\
\text { ficados, até o limilc das vagas pre- } \\
\text { vistas no edital, dentro do prazo } \\
\text { de validade do concurso (ar1. 9:). }\end{array}$ & - \\
\hline$\sum$ Estágio Probatório & $\begin{array}{l}1 \text { ano (art. IS, alterado pela Lei n: } \\
2.735 \text {, de } 18 / 02 / 56 \text { ) }\end{array}$ & a1e 2 anos (art. 17) & - \\
\hline 6 Redistribuiçăo & - & $\begin{array}{l}\text { deslocamenio do cargo com o req- } \\
\text { pecrivo ocupanie para oulto qua- } \\
\text { dro de pessoal, sem prejuizo para } \\
\text { o funcionário (ar1s. } 37 \text { e } 38 \text { ). } \\
\end{array}$ & $\begin{array}{l}\text { Este institulo está previsto no } \\
\text { art. 99 do Decreło-lei n. } \\
200 / 67\end{array}$ \\
\hline 7 Substituiçăo & $\begin{array}{l}\text { é remunerada a substituição auto- } \\
\text { mática quando superior a } 30 \text { dias } \\
\text { (arr. 73) }\end{array}$ & $\begin{array}{l}\text { a substituição é remunerada qual- } \\
\text { quer que scja a sua natureza c pe- } \\
\text { riodo (arı. 39. parágrafo único) } \\
\end{array}$ & \\
\hline $\begin{array}{l}\text { A Ajuda de cusı́o à familia } \\
\text { do [uncionário para :e- } \\
\text { corno à localidade de on- } \\
\text { gem }\end{array}$ & - & $\begin{array}{l}\text { e devida quando ocorre o faleci- } \\
\text { mento do funcionadrio, dentro do } \\
\text { prazo de } 1 \text { ano, que no interesse } \\
\text { do serviço. passou a ter exercicio } \\
\text { em nova sede (ar1, } 49, \S 2 \text {.) } \\
\end{array}$ & \\
\hline$Y_{\text {le }}$ & - & $\begin{array}{l}\text { devida ao funcionário que sistema- } \\
\text { ticamente executar serviços exter- } \\
\text { nos, por fosça de seu casgo (art. } \\
\text { s5) }\end{array}$ & \\
\hline
\end{tabular}




\begin{tabular}{|c|c|c|c|}
\hline ESPECIFICAÇÃO & ESTATUTO ATUAI. & ANTEPROJETO INTERCAMERAL & OHSERVAÇÃO \\
\hline Auxílio-saúde & $\begin{array}{l}\text { imporância equivalente a } 1 \text { mês de } \\
\text { remuneraçāo, após } 12 \text { meses de li- } \\
\text { cença por doença especificada em } \\
\text { lei (art. 143) }\end{array}$ & $\begin{array}{l}\text { igual importância, após } 6 \text { meses, } \\
\text { conjemplando, além das doenças } \\
\text { especificicadas em lei, o acidente em } \\
\text { serviço e as moléstias profissionais } \\
\text { (ar1. 58) }\end{array}$ & \\
\hline Auxílio-natalidade & - & $\begin{array}{l}\text { importância equivalente a } 2 \text { vezes } \\
\text { o menor valor da escala de venci- } \\
\text { mentos do funcionalismo civil da } \\
\text { Uniảo (art. 63) }\end{array}$ & \\
\hline 2 Gratificaçâo Adicional & $\begin{array}{l}5 \% \text { do vencimenı por qüinqüêe- } \\
\text { nio (art. } 146 \text {, alterado pela I ei no } \\
4.345 \text {, de } 26 / 06 / 64 \text {, ar1, 10) }\end{array}$ & I\% do vencimenı ао ало (arı. 64 ) & \\
\hline 3 Gratîlicaçāo Natalina & - & $\begin{array}{l}\text { 1/12 da remuneração devida no } \\
\text { mês de de`embro (arl, 68) }\end{array}$ & $\begin{array}{l}\text { A gralificação em apreço será } \\
\text { também paga aos inarivos e } \\
\text { pensionislas, na forma do art. } \\
68 \text { do anteprojelo. } \\
\end{array}$ \\
\hline $\begin{array}{l}\text { A Conversāo de } \mathbf{1} / \mathbf{3} \text { das } \\
\text { férias em pecúnia } \\
\end{array}$ & - & Sim (arl. 73) & \\
\hline$\sum_{\text {va }}^{\text {Licença à Mãe Adoti- }}$ & - & $\begin{array}{l}\text { a funcionária que adolar criança } \\
\text { de alé } 5 \text { anos de idade Iem direito } \\
\text { a } 60 \text { dias de licença remunerada } \\
\text { (arı. 84) }\end{array}$ & \\
\hline 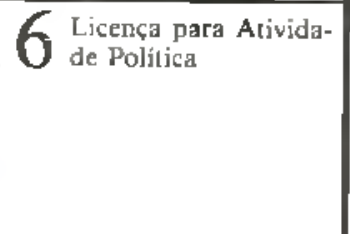 & - & $\begin{array}{l}\text { sem remuneraçăo, no período que } \\
\text { mediar entre a sua escolha, na con- } \\
\text { venção parlidária, e a véspera do } \\
\text { efelivo registro de sua candidaru- } \\
\text { ra; com remuneraçăo, a partir do } \\
\text { regisıro da candidasura até o 15. } \\
\text { dia seguinte ao da eleição (art. 87) }\end{array}$ & $\begin{array}{l}\text { Matéria regulada em lei espe- } \\
\text { cial (Lei no } 6.978 \text {, de } 19 / 01 / 82 \text {, } \\
\text { art. I0) }\end{array}$ \\
\hline 7 Licença Especial & $\begin{array}{l}6 \text { meses, apóśs cada decênio de efe- } \\
\text { livo exercício (art. II6) }\end{array}$ & $\begin{array}{l}3 \text { meses, após cada qüinqüênio de } \\
\text { efetivo exercício (art. 88) }\end{array}$ & \\
\hline $\mathbf{Q}$ Licença para Mandato & - & $\begin{array}{l}\text { a licença é concedida pelo prazo } \\
\text { de duração do mandalo, admisida } \\
\text { a prorrogaçāo, no caso de reelej- } \\
\text { çẫo, por yma única vez (arı. 9l) }\end{array}$ & \\
\hline $\begin{array}{l}\text { Q Contagem do tempo } \\
\text { de serviço de licença } \\
\text { para tratamento da } \\
\text { própria saúde }\end{array}$ & 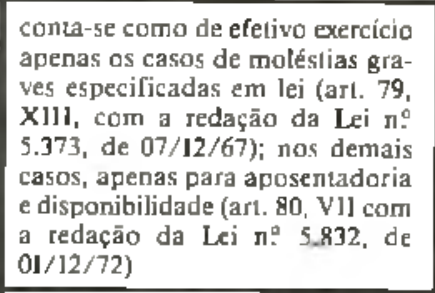 & $\begin{array}{l}\text { conla-se, em todos os casos, como } \\
\text { de efetivo exercicio (arl, } 95, \mathrm{XII} \text { ) }\end{array}$ & \\
\hline Ingresso em juizo & $\begin{array}{l}\text { o funcionário é obrigado a comu- } \\
\text { nicar o falo ao chefe imedialo (an. } \\
\text { 172) }\end{array}$ & $\begin{array}{l}\text { paralisa a instância adminisırati- } \\
\text { va (art. 108) }\end{array}$ & $\begin{array}{l}\text { A formulaçāo n. } 34 \text { do DASP } \\
\text { dispơe que o ingresso na via ju- } \\
\text { dicial imporia em desistência } \\
\text { da va administrativa. }\end{array}$ \\
\hline $\begin{array}{l}\text { Aposentadoria provi- } \\
\text { sória }\end{array}$ & - & $\begin{array}{l}\text { após } 24 \text { meses de licença para tra- } \\
\text { tamento de saúde, o funcionário } \\
\text { que nâo tiver condiçōes de reassu- } \\
\text { mir o seu cargo ou de ser readap- } \\
\text { lado seráa aposentado provisoria- } \\
\text { mente, devendo, nos } 5 \text { anos sub- } \\
\text { seqüentes, submeler-se à perícia } \\
\text { médica anual, que constazando a } \\
\text { permanência da invalidez, lorna- } \\
\text { rá o ato definirivo (art. } 117, \S \mathrm{I} \text {. } \\
\text { a 5:) } \\
\end{array}$ & $\begin{array}{l}\text { VIDE Lei n: 7.0்l6, de } 23 / 0 \overline{8} \\
82 \text {, que disciplina a reversäa, a } \\
\text { qual tem pontos em comum } \\
\text { com o instituto em comenlo. }\end{array}$ \\
\hline
\end{tabular}




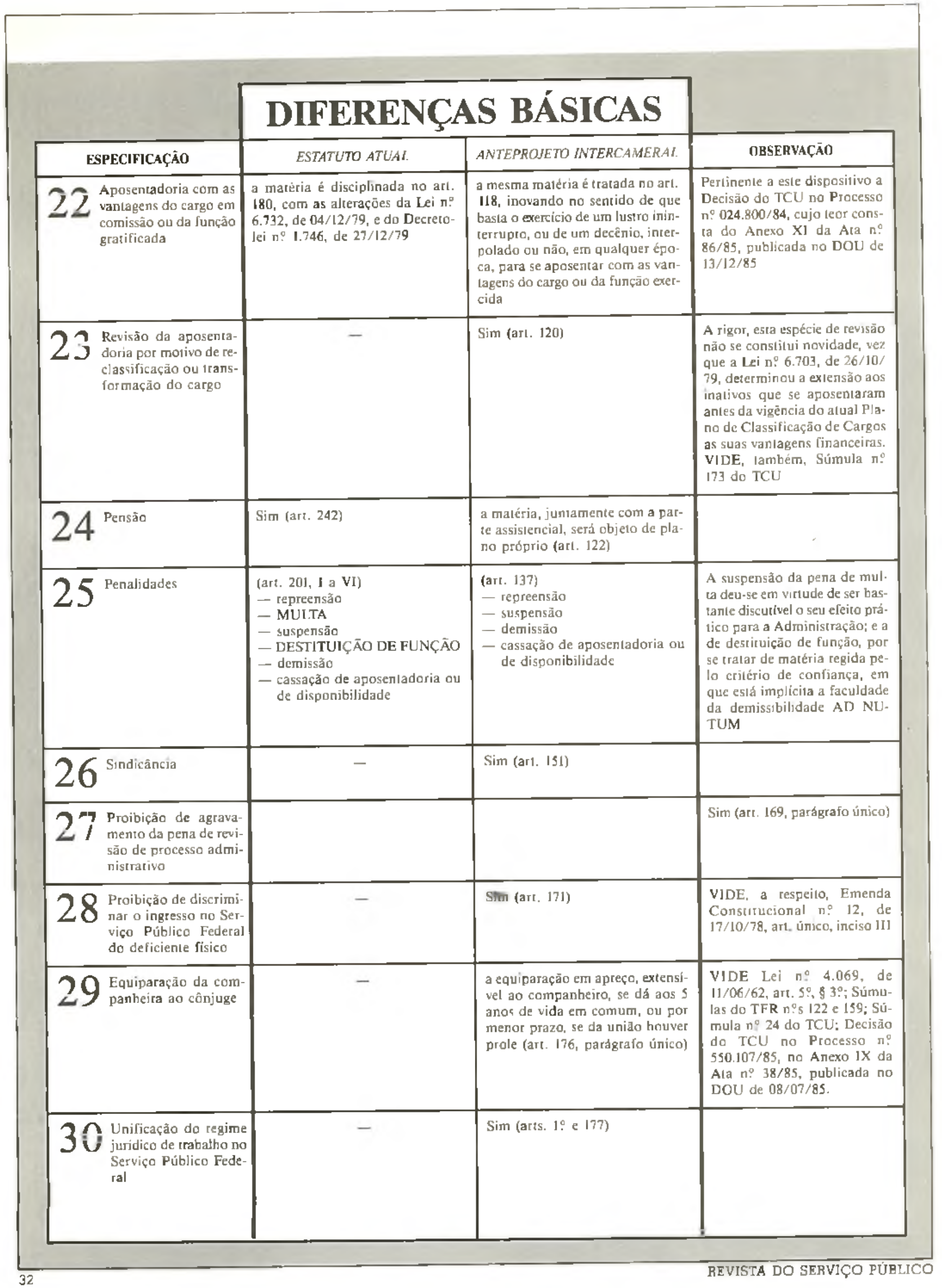

